\title{
Supervision Models in Psychological Counseling
}

\author{
Serdar KÖRÜK, Ahmet KARA*
}

\begin{tabular}{l} 
Supervision Models in Psychological Counselling \\
Abstract \\
In this review, supervision models used in the psychological \\
counseling process are examined. In the literature, supervision \\
models are classified under three headings; psychotherapy- \\
based supervision models, developmental supervision models, \\
and social-role models. Psychotherapy-based supervision \\
models are divided into three subgroups. These are, Working \\
Alliance Model, Behavior-Analytic Model and Cognitive Skills \\
Model. Developmental supervision models are divided into four \\
subgroups. These are, Integrated Development Model, \\
Reflective Model, Conceptual Model and Developmental \\
Comprehensive Supervision Model. Lastly, social-role models are \\
divided into two subgroups. These are, Discrimination Model \\
and Holloway's System Approach Model. The mentioned \\
models are discussed in the scope of their functionality in the \\
supervision process, their basic philosophies and their stages. \\
\hline
\end{tabular}

Key Words: Supervision, Model, Psychology, Psychological Counseling

\author{
Psikolojik Danışmada Süpervizyon Modelleri \\ Özet
}

Bu gözden geçirme çalışmasında, psikolojik danışma sürecinde kullanılan süpervizyon modeller incelenmiştir. Alan yazında süpervizyon modelleri üç başlık altında sınıflandırımakta olup bunlar; psikoterapi temelli süpervizyon modelleri, gelişimsel süpervizyon modelleri ve sosyal rol modelleridir. Psikoterapi temelli süpervizyon modelleri üç alt gruba ayrılmaktadır. Bunlar; Çalışma Uyumu Modeli, Davranış̧̧-Analitik Model ve Bilişsel Beceri Modelidir. Gelişimsel süpervizyon modelleri dört alt gruba ayrılmaktadır. Bunlar; Bütünleşik Gelişimsel Model, Yansıtıc Model, Kavramsal Model ve Gelişimsel Kapsamlı Modeldir. Son olarak sosyal rol modelleri iki alt gruba ayrılmaktadır. Bunlar; Ayrıştırıcı Model ve Holloway'in Sistem Yaklaşımıdır. Bu makalede belirtilen modeller, süpervizyon sürecindeki işlevsellikleri, temel felsefeleri ve aşamaları doğrultusunda tartışılmıştır.

Anahtar Kelimeler: Süpervizyon, Model, Psikoloji, Psikolojik Danışma

\section{Introduction}

Supervision is defined as the process by which experienced professionals (supervisor) prepare less professional colleges for their profession and provide them with supportive and evaluative services to enrich their practise experience (Bernard \& Goodyear, 2009). In the field of psychological counseling, the professional training of members who are new to the profession is very important for the professionality of the counseling process (Everet ve Koerpel, 1986). In the supervisory relationship, the supervisor is expected to transfer his knowledge and experience to supervise and create a safe environment for him/her to develop his/her therapeutic knowledge (Haynes, Corey ve Moulton, 2003).

\footnotetext{
* Serdar KÖRÜK, Arş. Gör., Faculty of Education Psychological Counseling and Guidance Department in Eskisehir Osmangazi University, serdarkoruk1989@gmail.com_ORCID: 0000-0003-3170-4302, Ahmet KARA, Arş. Gör., Faculty of Education Psychological Counseling and Guidance Department in Eskisehir Osmangazi University, ahmetkara9126@gmail.com,_ORCID: 0000-0002-1155-619X
} 
The main aims of supervision in the literature are as follows; a) to increase the competence of the supervisee, b) to help the supervisees integrate their knowledge and practice experiences to enable them to be effective in their psychological counseling relationship with their clients in their professions, c) to monitor the goodness of the supervisees receiving supervision and to check whether they act in the frame of professional ethics (Atık, Arıcl, \& Ergene, 2014). According to CACREP, which sets standards and accreditations in psychological counseling education in the United States, 100 hours of psychological counseling under professional supervision should be conducted during in an academic year as a training requirement and for the professional accreditation, 600 hours of psychological counseling under professional supervision should be conducted. To the EAC, which sets standards in the European Union, 100 hours of psychological counseling should be done in an academic year as a training requirement and for the professional accreditation, 450 hours of psychological counseling under professional supervision should be conducted (Körük, 2018). Considering the requirements, for the profession to be done professionally, the importance of effective and qualitative supervision is seen.

When the history of psychological counseling profession and its training process in Turkey is examined, developments that started in the 1950s, matured in 1982 with the establishment of the first undergraduate program (Korkut, 2007). In Turkey, there is official institution which determines the accreditation of both training supervision and professional supervision in the field of psychological counseling. Undergraduate students conduct individual counseling sessions, which's number vary to the department, in the individual counseling practice course they take at last year and receive supervision from their instructors. At this point, there is no professional association between the faculties in such areas as the way supervision is given and which perspectives are based (Siviş-Çetinkaya \& Karaırmak, 2012).

In this context, the main purpose of this article is to inform the professionals in the field of psychological counseling about supervision models and theories they are based on. In the field of psychological counseling, it seems that there are many supervision models in literature (Blocher, 1983; Hosford \&Barmann, 1983; Page \&Wosket, 2001; Ward \& House, 1998) but in general, supervision models are classified as psychotherapy-based supervision models, developmental supervision models and social- role models (Atık, Arıcl, \& Ergene, 2014).

\subsection{Psychotherapy-based Supervision Models}

Psychotherapy-based supervision models are based on the assumption that the supervision process has similarities with the psychological counseling process and that the approaches used in the counseling process can be used between the supervisor and supervisee in the supervision (Freeman \& McHenry, 1996). Psychotherapy-based supervision models are divided into three subgroups. These are, Supervisory Working Alliance Model, Behavior-Analytic Model and Cognitive Skills Model. 


\subsubsection{Working Alliance Model}

Developed by Bordin (1979) on supervision in psychological counseling, Working Alliance Model includes the transfer of psychoanalysis-based concepts and psychotherapy elements to the supervision process. The dynamic-based therapy relationship between the psychotherapist and the client is reflected in the supervision relationship between supervisor and supervisee (Horvath \& Greenberg, 1994). According to this model, the main factor underlying the success of the supervision process is the attachment and alliance between the supervisor and supervisee. Bordin (1994) defined three important dimensions of the supervision process in his model. These are; shared goals, mutual duties and mutual attachment of the supervisor and supervisee. Attachment dimensions include mutual trust, respect, and care (Bradley \& Ladany, 2001). It is stated that the time spent together during supervision should strengthen this bonding. The shared goals dimension is determined by the conflict and agreement between the supervisor and the supervisee (Wood, 2005). The main purpose here is to make the supervisee more aware of himself / herself and to determine which professional skills he / she will attain. In terms of mutual duties, the supervisor is actively involved. The supervisee is constantly being assessed by the supervisor on issues such as increasing personal awareness, the development of theoretical knowledge and counseling skills (Wood, 2005). Understanding the individual factors that prevent the supervisee from acquiring professional qualifications and trying to overcome these factors are the main objectives of the supervision. At this point, the supervisor is responsible for giving feedback and responding to the needs of the consultant. In the supervision process, strength and dominance are in the hands of the supervisor in general, and the supervisor can share this power from time to time, focusing on the supervisee's feelings and on the thoughts of the supervision process. The general view of the supervision process is shown in Figure 1. 
Serdar KÖRÜK | Ahmet KARA

Figure 1

Working Alliance Model Supervision Process

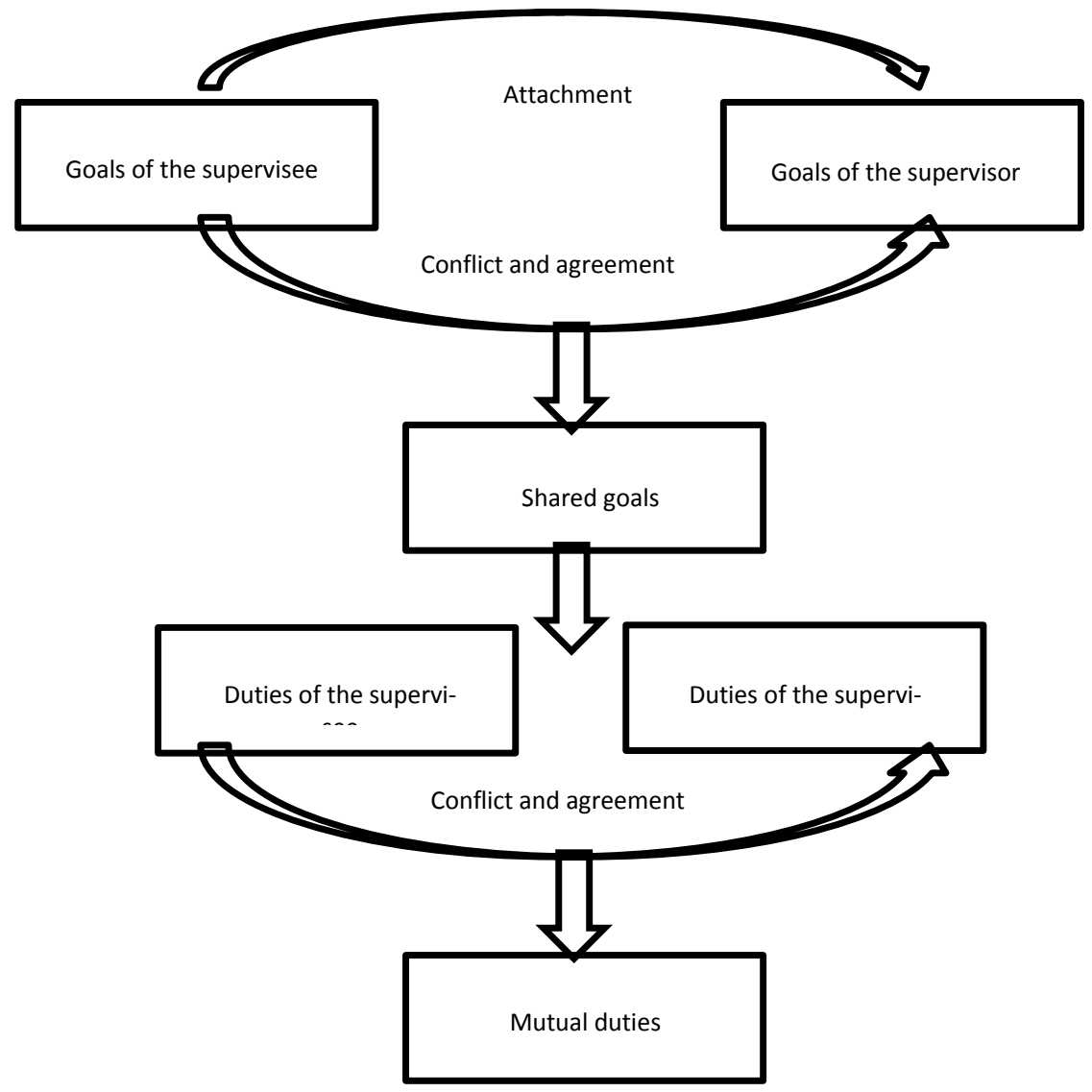

The most important element in this model is the provision of the internal vision of the supervisee through the interaction between the supervisee and the supervisor. There are some limitations to this point. Relations and interactions between people can be differentiated from culture to culture, and at this point, the supervisor needs to apply this model with a culturally sensitive approach. Another limitation is that, as Borders (2009) points out, the supervision process is more likely to turn into a psychological counseling process.

\subsubsection{Behavior-Analytic Model}

Behavioral supervision model is similar to behavioral psychotherapy school. The support of functional clinical skills and the prevention of dysfunctional clinical skills take place within a teach- 
ing approach (Follette \& Callaghan, 1995). It is the most important elements of this model that the supervisor gives visually feedbacks of the sessions through the video recordings. After the first two sessions between the supervisor and the supervisee, the supervisor and the supervisee determine the clinical skills that need to be focused. These skills are classified as useful and problematic. The supervisee then records the sessions as video for analysis and analyzes each session are conducted with the supervisor. This situation is called as management from the room. Sessions are being analyzed for minutes. In this process, the supervisor can role-play, model, and show the supervisee what he / she thinks is problematic. The reactions considered to be dysfunctional in the counseling process are handled one by one. The functionality and dysfunctionality of the reactions are analyzed based on the evaluations of the supervisee.

This model is seen as a more mechanistic model since it improves the skills that are effective in the counseling process and directly addresses the reduction of dysfunctional skills in a corrective and instructive way. The flexibility of the supervisee is more limited in this model (Bradley \& Gould, 2001).

\subsubsection{Cognitive Skills Model}

The cognitive skills model aims to improve the cognitive skills of supervisees that guide counseling processes. There are three basic cognitive skills and four main parts (Morran, Kurpius, Brack \& Brack, 1995). This model contains didactic elements. This model is an economic model in terms of structure, tutorial and time. In the process of psychological counseling, difficulties are addressed, dysfunctional cognitions are revealed, and solutions are sought in cooperation (Bernard \& Goodyear, 2009).

The first stage of the model is promoting awareness of cognitions. At this stage, the supervisee is expected to search the relevant literature and strengthen the theoretical knowledge. The supervisee also focuses on his own cognitive processes at this stage. The second stage is introducing the cognitive skills. Three basic cognitive skills; to obtain information, to create hypotheses and to plan intervention and self-management are introduced to the supervisee. The third stage is the trainee cognitive self-assessment. The model, which has more didactic features until this stage, focuses on the applications of the supervisee at this stage. Registered counseling sessions are subject to cognitive analysis in the direction of the supervisor's directions. The supervisee reapplies the cognitive skills he uses in counseling and analyzes his / her functioning. The fourth and final stage is cognitive-skill practice. At this stage, supervisees are encouraged to systematically apply the skills they have learned in previous phases. These systematic practices can be a counseling process, role play or hypothesis formation through a case presented.

This model focuses more on supervisees' beliefs, thoughts and cognitive processes in the supervision process. It has teaching and guidance elements. Cultural factors should be considered at this point because the systems of thought and belief can show differences between cultures. Therefore, the supervisor needs to raise awareness among cultures. 
Serdar KÖRÜK | Ahmet KARA

\subsection{Developmental Supervision Models}

Developmental supervision models are based on the principles of developmental psychology in the supervision process. According to the needs of supervisees and clients, the psychological counseling process should be shaped in certain stages and in the same way the supervision process must proceed in certain stages (Goodyear \& Bradley, 1983; Stoltenberg, 1981).

\subsubsection{Integrated Developmental Model}

Developed by Stoltenberg (1981), this model is the most well-known and widely used developmental model. According to this model, the supervisee passes through four stages in the supervision process and is evaluated in three basic dimensions (Stoltenberg, 1993). These three basic dimensions are identified as awareness for the client's world, motivation, and autonomy. In addition to these four stages and three basic dimensions, Stoltenberg, McNeill and Delworth (1998) identified eight professional functions that must be won by supervisees. These; intervention skills are classified as competence in intervention skills, evaluation techniques, individual / cultural differences, interpersonal evaluation, theoretical orientation, conceptualization of the problem, intervention plans and objectives, and professional ethics.

Supervisees who are new to the supervision process are in the first stage. These supervisees have low awareness of their clients' worlds, high motivation as well as high levels of anxiety due to lack of experience. Supervisees are dependent on the supervisor because their knowledge of what to do in the counseling process is insufficient and therefore their levels of autonomy are low. They need to be structured by the supervisor and receive positive and negative feedbacks.

Supervisees in the second stage are becoming more ready to experience emotional and cognitive experiences with their clients. Their awareness of their clients' worlds is starting to increase. Their motivations are as high as in the first stage, but their motivations may fall rapidly in situations where supervisees do not fit or feel insecure. On the autonomy side, supervisees will continue to have high supervisory dependencies, while the successes in the counseling process will encourage them to become more autonomous. The tendency to get more autonomy, in the event of a possible failure and insecurity, turns into a tendency to become dependent on the supervisor. The second stage is generally turbulent and requires significant skills and flexibility (Stoltenberg, 1993).

The third stage is called conditional dependency. At this stage, as the supervisees' emotional and cognitive awareness of their clients' world increases, their insights are also increasing. The supervisee is able to follow the psychological counseling process more effectively and becomes more open to working with different clients through increased empathy (Çetinkaya \& Kararmak, 2012). At this stage, fluctuations in the motivation of the supervisees are diminishing and the level of motivation becomes more stable. Self-confidence and empathy levels are rising at this stage. Supervisors should encourage their supervisees at this stage in fields where they are functional and successful. In this way, supervisees become more autonomous and take initiative. 
At the last stage, supervisees are seen as expert professionals (Stoltenberg, 1981, 1993). At this stage, they are now in the process of integrating their intervention, evaluation and conceptualization skills. Supervisees have provided self-awareness, and the supervisory relationship is transformed into a professional colleague. Supervisees are able to face more successfully the problems they encounter during the counseling process. They are able to accept comfortably at this stage that encountering difficulties in the profession is a natural aspect of development.

The most important criticism directed at developmental models is the difficult and complicated application of the model (Ellis \& Ladany, 1997). It is mentioned that there is a need to find simpler norms about which interventions should be used in which stage. In addition, criticisms are made regarding the extent to which environmental factors are taken into account in determining the stages and interventions.

\subsubsection{Reflective Model}

Reflective Supervision Model has the elements transferred from Reflective Instructional Model to the supervision process. According to Mezirow (1994), critical reflections on interactions and assumptions play an important role in the formation of meaningful learning. In this model, it is necessary to redefine the disturbing, dysfunctional counseling situations of the supervisees in a meaningful and active way in the forming of problem solving skills. This model consists of four phases shown in Figure 2. The first stage is defined as Contextual Orientation. At this stage, supervisees may feel feelings like anxiety, desire to be perfect, confusion and anger. For professional development, supervisees should overcome these feelings (Ward \& House, 1998). In this context, it is recommended to focus on the following point of the supervision process in the first stage; to show the difference between the acquisition of academic understanding and clinical skills, to prevent the supervisee from over-taking the responsibilities and urgency of the counseling process, and how to use the ethical principles in the counseling process. The second phase of the model is defined as Building Trust. At this stage, the supervisor provides a positive learning environment so that the supervisee can learn about the incompatible counseling experiences by providing him / her non-judgmental, supporting and affirmative feedbacks. The third stage is the Conceptual Development phase. At this stage, the supervisor tries to reinforce the conceptual knowledge of the supervisee with reflective dialogue and reflective inquiry. In this way, incompatible counseling experiences are transformed into meaningful schemas. The final stage is Clinical Autonomy. At this stage, candidates are encouraged to take their professional autonomy in the areas of selfassessment and case planning / management.

An important focus of reflective supervisory dialogues is to guide the supervisee in a particular way, focusing on the themes of the counseling process, rather than on the content the supervisee brings about the counseling process. Open-ended thematic inquiries and observations are focusing on the process of supervision rather than focus on content. Another important feature of reflective dialogue is that supervisees are able to make self-evaluation. Open-ended thematic assessments enable supervisees to make objective assessments of their clients' needs. 
Serdar KÖRÜK | Ahmet KARA

Figure 2

Reflective Model Four Phases

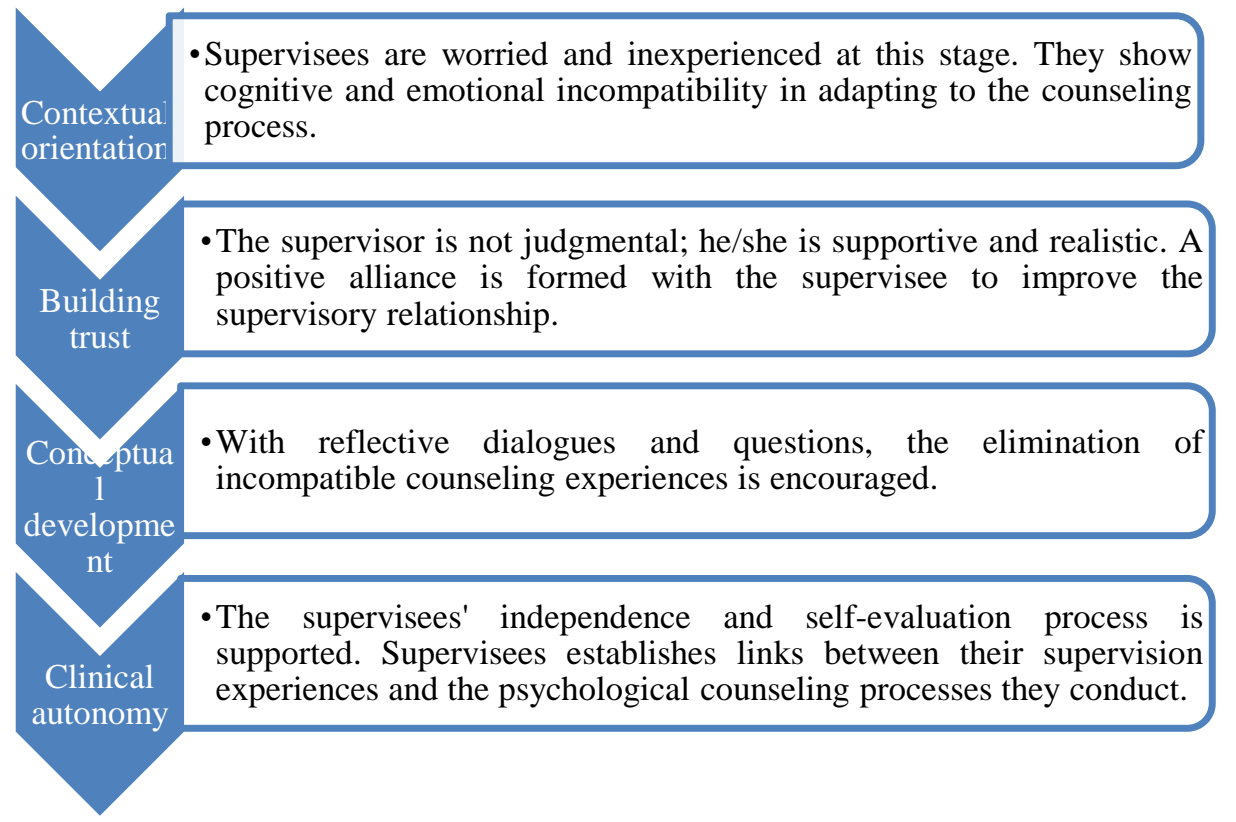

\subsubsection{Conceptual Model}

This model, developed by Loganbill, Hardy and Delworth (1982), consists of three stages. These stages are stagnation, confusion and integration. In addition, this model focuses on eight developmental topics in the supervision process. These are; competence, emotional awareness, autonomy, theoretical identity, respect for individual differences, purpose and direction, personal motivation, and professional ethics. In this model, the supervisee can be in any one of three stages in any topics. There is a non-linear, circular process. Loganbill et al. (1982) mentioned that counselor development is continuous, and supervisees can cycle and recycle through these stages and topics over time. The supervisor's responsibility is to deepen and enrich the experience of each stage and guard against the supervisee's premature movement.

In stagnation stage, the supervisee is likely unaware of himself/herself and his/her psychological counseling process. He/she has difficulty in developing insight against the client's reactions. $\mathrm{He} /$ she cannot be multi-dimensional and is extremely dependent on his supervisor. During confusion stage, a shift occurs in the supervisee's cognitive world and he/she starts to move from traditional way of thinking related to his/her psychological counseling sessions. This creates a disequilibrium and ambivalence. In the last stage integration, distorted equilibrium is provided again, the supervisee organizes new information, develops a new understanding and starts to think flexible (Loganbill et al., 1982). 


\subsubsection{Developmental Comprehensive Supervision Model}

Eryllmaz and Mutlu $(2013,2016)$ developed a supervision model for psychological counselor candidates based on the developmental perspective. The model's name is Developmental Comprehensive Supervision Model. The model consists of three phases and six stages. Each phase consists of two sub-stages. Three phases are strengthening (readiness and informing stages), development (intervention and intervision stages), and evaluation (evaluation of development and evaluation of supervision model)

Strengthening phase consists of readiness and informing stages. In readiness, supervisees are assessed for their level of readiness for three levels of psychological counseling competence, including therapeutic skills, therapeutic conditions and managing the therapeutic process. In informing stage, it is aimed to develop supervisees' psychological counseling competencies in three dimensions including therapeutic skills, therapeutic conditions and managing the therapeutic process by giving seminars for the developmental model and problem solving stages.

Development phase consists of intervention and intervision stages. In intervention, it is expected that supervisees will be able to intervene more effectively in the problems of their clients. In this aim, supervisees are given assignments that will enable them to increase their knowledge about clients' problems. In intervision, intervision sessions are conducted and supervisees are asked to form groups of three or four to discuss their psychological counseling processes and the problems of their clients.

Evaluation phase consists of evaluation of development and evaluation of supervision model stages. At evaluation of development stage, supervisees are assessed for psychological counseling competencies in three dimensions, including therapeutic skills, therapeutic conditions and managing the therapeutic process. In the last stage, undergraduate supervisees' psychological counseling qualifications are determined by comparing the visa and final grades.

\subsection{Social-Role Models}

Supervision models within the Social-Role Model focus on the role of the supervisor in the supervision process, the transitions between these roles, and the function of each role. While roles determine the supervisor's position, the functions of roles include the areas that the supervisee should learn (Atik, Arıcı \& Ergene, 2014, Çetinkaya \& Kararmak, 2012). The Discrimination Model developed by Bernard (1979) and the System Approach Model developed by Holloway (1995) are social-role modeled supervision approaches.

\subsubsection{Discrimination Model}

In this model, developed by Bernard (1979), the supervisee is aimed to gain process, conceptualization and personalization skills. Supervisor assumes the role of teacher, psychological counselor and consultant in the acquisition of these skills. The matrix of this model is shown in Figure 3. 
Serdar KÖRÜK | Ahmet KARA

Figure 3

\begin{tabular}{lll}
\multicolumn{3}{c}{ Discrimination Model Matrix } \\
\hline Function & Supervisor's Roles & Phase \\
\hline Process & Teacher & Beginning \\
\hline Conceptualization & Counselor & Development \\
\hline Personalization & Consultant & Maturity
\end{tabular}

The supervisor in the role of teacher aims to teach the knowledge that he has. The main purpose is to acquire the skills required by the psychological counseling process (Bradley, Gould \& Parr, 2001). The supervisor in the role of psychological counselor focuses on the individual experiences of the counseling process of the supervisee. As a psychological counselor, the supervisor uses the psychological counseling skills to reveal the dynamics of the supervisee and is concerned with supervisee's personal development needs (Borders \& Brown, 2005). The supervisor in the consultant role supports the autonomy of the supervisee more and establishes an equal professional relationship with him/her. The consultant aims to increase the responsibility for the supervisee and reveal his/her own counseling management skills.

The topics covered in the process phase are generally intervention skills and psychological counseling skills. The conceptualization step is the phase in which the connections between theoretical knowledge and practice are established. At this stage, the supervisee explores the behavior patterns of the clients and his/her own behavior patterns, hypothesizes the problems of their clients, sets goals and makes appropriate intervention choices. The focus of the personalization phase is that the supervisee can create his/her own style, receive feedback from the supervisor without resistance, be aware of his/her values, and adopt a non-judgmental attitude (Bernard, 1979). The most important limitation of this model is that it does not focus as much on the supervision process. It is suggested that there is not much emphasis on supervisory relations in this model, where the roles and duties required by roles and transitions between roles are more important (Bradley, Gould \& Parr, 2001).

\subsubsection{Holloway's System Approach Model}

This model, developed by Holloway (1995), examines the supervision relationship in three basic elements shown in Figure 4. The first element of the model is the establishment of the supervision relationship. Here the emphasis is placed on the interpersonal aspects of the relationship involving strength and participation in the relationship. The interpersonal aspects of the relationship directly affect the quality of the supervision. The supervisor is obliged to teach his / her knowledge to the supervisee at this point and evaluate his / her success. The second element is the supervision contract. This contract is a mutual agreement that explains the expectations of the supervisor and the supervisee about the process, determines the purpose and tasks, and explains the content, qualifications and evaluation elements of the relationship. Skovholt (1993) stated that this contract must be four-dimensional. These four dimensions; supervisor competencies at all levels, facilities to be provided in the institution where the field application is made, needs for the 
developmental level of the supervisee, and supervision objectives, methods and focus. The last element is the stages of the supervision relationship. In Holloway's model, the process is divided into three phases. These are beginning, maturity and termination. The initial phase is the first phase in which the relationship is established, the interpersonal work begins to form, and the supervision agreement is made. At maturity, the supervisor works with the supervisee by managing and evaluating the supervisee in psychological counseling skills, case conceptualization, emotional awareness, professional roles and self-assessment. In the termination phase, as in the other models, the autonomy of the supervisee is supported and the supervisee is expected to need less supervision.

Figure 4

Holloway's System Approach Model

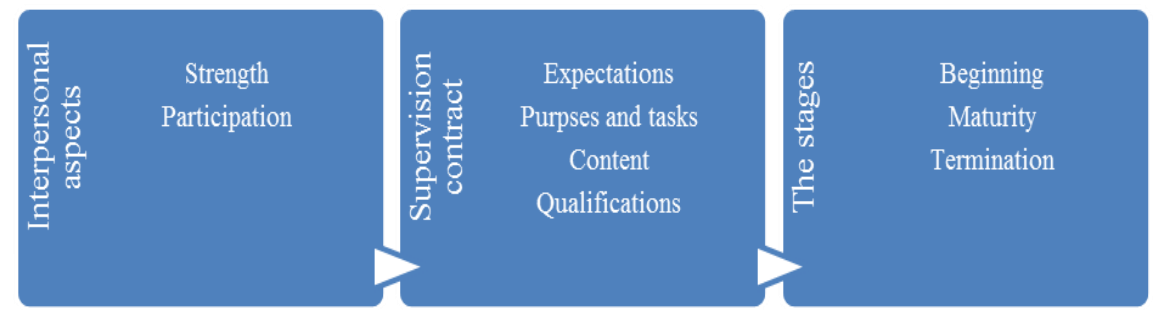

\section{Supervision Formats}

Supervision can be done with individual, triple or group (Barletta, 2007). In the individual supervisor, while the teacher works with a candidate, the supervisor in the triple supervisor works with two counselors. In the group supervision, the supervisor works with a group of at least three and a maximum of twelve supervisees. While the individual supervisor has advantages such as supervisor being able to focus more and to spend more energy on the process, on the other and in triple and group supervision, the supervisor has advantages such as development of interpersonal skills and reduction of supervisor dependence (Borders \& Brown, 2005).

\section{Discussion}

As seen, there are different supervision approaches in psychological counseling. Psychotherapy-based supervision models reflect aspects of psychological counselor-client relationship into supervisor-supervisee relationship and based on therapeutic relationship elements. Developmental supervision models consider the needs of the supervisee and try to meet these needs from basic-simple to more complex through developmental stages. Social-role models focus on the perceived role of supervisor from the supervisee's perspective and the functions and necessities of each role over the supervisee. 
It can't be empirically claimed that any model has superiority to any other (Sprenkle, 1999; Storm, Todd, Sprenkle \& Morgan, 2001). Each model has its own theoretical foundations, way to handle the supervisees' development and its own methods to train the supervisees. If supervisors belongs to or feel close to any therapy school, they can use the supervision approach close to that therapy school. It can be claimed that conducting the process in a professional manner depending on the rules of a certain approach will contribute more to the enrichment of the supervisees.

\section{Kaynaklar}

Atik, Z. E., Arıcı, F., \& Ergene, T. (2014). Supervision models and assessments of the model. Turkish Psychological Counseling and Guidance Journal, 5(42), 305-317.

Barletta, J. (2007). Clinical supervision. N. Pelling, R. Bowers ve P. Armstrong (Eds.), The practice of counselling. Melbourne, Australia: Thomson.

Bernard, J. M. (1979). Supervisor training: A discrimination model. Counselor Education and Supervision, 19(1), 60-68.

Bernard, J. M., \& Goodyear, R. K. (2009). Fundamental of clinical supervision. (4th ed). NJ: Pearson Education,

Blocher, D. H. (1983). Toward a cognitive developmental approach to counseling supervision. Counseling Psychologist, 11(1), 27-34.

Borders, L. D. (2009). A primer on counseling supervision. İçinde F. Korkut Owen, R. Özyürek, \& D. W. Owen (Ed.), Gelişen psikolojik danışma ve rehberlik: Meslekleşme sürecinde ilerlemeler. Ankara: Nobel Yayın Dağııım.

Borders, L. D., \& Brown, L. L. (2005). The new handbook of counseling supervision (2nd ed.). NJ: Lawrence Erlbaum Association.

Bordin, E. S. (1979). The generalizability of the psychoanalytic concept of the working alliance. Psychotherapy, Theory, Research and Practice, 16, 252-260.

Bordin, E. S. (1994). Theory and research on the therapeutic working alliance: New directions. A. O. Horvath, \& L. S. Greenberg (Eds.). The working alliance: Theory, research and practice. NY: Wiley\& Sons.

Bradley, L. J., Gould, L. J., \& Parr, G. D. (2001). Supervision-based integrative models of counselor supervision. In L. J. Bradley, \& N. Ladany (Eds.), Counselor supervision: Principles, process, and practice. Ml: Taylor \& Francis.

Bradley, L. J., \& Ladany, N. (2001). Counselor supervision: Principles, process, and practice (3rd ed.). Philadelphia: Brunner-Routledge.

Çetinkaya, R. S., \& Karaırmak, Ö. (2012). Supervision in counselor education. Turkish Psychological Counseling and Guidance Journal, 4(37), 107-121.

Ellis, M. V., \& Ladany, N. (1997). Inferences concerning supervisees and clients in clinical supervison: An integrative review. In C. E. Watkins (Ed.), Handbook of psychotherapy of supervision. New York: Willey.

Eryllmaz, A. \& Mutlu, T. (2013). Development of perceived self-efficacy in counseling competencies scale. International Symposium on Changes and New Trends in Education, 22 November -24 November 2013, Konya, Turkey. 
Eryılmaz, A., \& Mutlu, T. (2016). Kuramdan uygulamaya bireyle psikolojik danışma [Individual psychological counseling from theory to practice]. Ankara, Turkey: Anı Publishing.

Everett, C. A., \& Koerpel, B. J. (1986). Family therapy supervision: A review and critique of the literature. Contemporary Family Therapy, 8(1), 62-74.

Follette, W. C., \& Callaghan, G. M. (1995). Do as I do, not as I say: A behavior-analytic approach to supervision. Professional Psychology: Research and Practice, 26(4), 413-421.

Freeman, B., \& McHenry, S. (1996). Clinical supervision of counselors in training: A nationwide survey of ideal delivery, goals, and theoretical influences. Counselor Education and Supervision, 36(2), 144-158.

Goodyear, R. K., \& Bradley, F. O. (1983). Theories of counselor supervision: Points of convergence and divergence. The Counseling Psychologist, 11(1), 59-67.

Haynes, R., Corey, G., \& Moulton, P. (2003). Clinical supervision in the helping professions: A practical guide. Belmont, CA: Brooks/Gole Thompson Learning.

Holloway, E. (1995). Clinical supervision: A systems approach. Newbury Park, CA: SAGE.

Horvath, A. O., \& Greenberg, L.S. (1994). The working alliance: Theory, research, and practice. NY: John Wiley \& Sons.

Hosford, R. E. \& Barmann, B. (1983). A social learning approach to counselor supervision. The Counseling Psychologist, 11, 1, 51-58.

Korkut, F. (2007). Counselor education, program accreditation and counselor credentialing in Turkey. International Journal for the Advancement of Counselling, 29(1), 11-20.

Loganbill, C., Hardy, E., \& Delworth, U. (1982). Supervision: A conceptual model. The Counseling Psychologist, 10(1), 3-42.

Mezirow, J. (1994). Understanding transformation theory. Adult Education Quarterly, 44(4), 222232.

Morran, D. K., Kurpius, D. J., Brack, C. J., \& Brack, G. (1995). A Cognitive skills model for counselor training and supervision. Journal of Counseling \& Development, 73(4), 384-389.

Page, S. \& Wosket, V. (2001). Supervising the counsellor: A cyclical model. NY: Routledge.

Siviş-Çetinkaya, R. ve Karaırmak, Ö. (2012). Psikolojik danışman eğitiminde süpervizyon. Türk Psikolojik Danışma ve Rehberlik Dergisi, 37 (4), 107-121.

Stoltenberg, C. (1981). Approaching supervision from a developmental perspective: The counselor complexity model. Journal of Counseling Psychology, 28(1), 59-65.

Stoltenberg, C. D. (1993). Supervising consultants in training: An application of a model of supervision. Journal of Counseling \& Development, 72(2), 131-138.

Stoltenberg, C. D., McNeill, B., \& Delworth, U. (1998). IDM supervision. San Francisco: Jossey-Bass Publishers.

Ward, C. C., \& House, R. M. (1998). Counseling supervision: A reflective model. Counselor Education and Supervision, 38(1), 23-33.

Wood, C. (2005). Supervisory working alliance: A model providing direction for college counseling supervision. Journal of College Counseling, 8(2), 127-138. 